\title{
Pengaruh Buku Cerita Bergambar terhadap Pengetahuan Manajemen Bencana Anak
}

\author{
Yeni Solfiah ${ }^{1}{ }^{\bowtie}$, Devi Risma ${ }^{2}$, Hukmi $^{3}$, Rita Kurnia ${ }^{4}$ \\ Pendidikan Guru Pendidikan Anak Usia Dini, Universitas Riau \\ DOI: $10.31004 /$ obsesi.v5i1.705
}

\begin{abstract}
Abstrak
Penelitian ini bermaksud membuktikan adanya pengaruh buku cerita bergambar berkaitan dengan pengetahuan manajemen bencana anak. Adapun metode penelitiannya merupakan eksperimen dengan bentuk quasi eksperimental design. Teknik pengambilan sampel dengan purposive sampling dengan jumlah 48 anak yang berada pada usia 5-6 tahun. Data pengetahuan manajemen bencana anak dikumpulkan dengan menggunakan tes pengetahuan tentang manajemen bencana. Adapun hasil dari studi ditemukan pengaruh buku cerita bergambar berkenaan dengan pengetahuan manajemen bencana pada anak. Dengan nilai $t_{\text {hitung }}=25,790$ dan probabilitas sig $\mathrm{t}=0,000$. Buku cerita bergambar memberikan pengaruh terhadap pengetahuan manajemen bencana pada anak sebesar 55,94\%. Kebaruan yang diperoleh dari penelitian ini adalah pentingnya memperkenalkan manajemen bencana kepada anak usia dini melalui sumber bacaan yang memiliki gambar sehingga pesan yang terdapat pada buku tersebut dapat tersampaikan dengan baik.
\end{abstract}

Kata kunci: buku cerita bergambar; manajemen bencana; anak usia dini.

\begin{abstract}
Abstrack
This study aims to determine the effect of picture books on children's disaster management knowledge. The method of this research is an experiment with a quasi-experimental design. And, the sampling technique uses purposive sampling with a total of 48 children who are aged 5-6 years. The data of child disaster management knowledge were collected by using a test about disaster management. The results of this study have the effect of picture books on disaster management knowledge for children. It is described by the value of $t=25.790$ and the probability of sig $t=0.000$. The picture book gives an influence on children's disaster management knowledge around 55.94\%. Therefore, it is important to introduce the disaster management to early childhood through reading sources that have pictures, so that the messages contained in the book can be conveyed properly.
\end{abstract}

Keyword: picture book; disaster management; early childhood.

Copyright (c) 2020 Yeni Solfiah, Devi Risma, Hukmi, Rita Kurnia

$\triangle$ Corresponding author:

Email Address : yeni.solfiah@lecturer.unri.ac.id (Pekanbaru, Riau, Indonesia)

Received 1 August 2020, Accepted 20 August 2020, Published 24 August 2020 


\section{PENDAHULUAN}

Berada di lingkaran api Pasifik serta pertautan tiga lempeng tektonik (Australia, Eurasia dan Pasifik) menyebabkan Indonesia menjadi negeri yang rawan bencana (Garschagen, 2016). Iklim tropis dikawasan ini berdampak pada rentannya terhadap kekeringan dan kebakaran di musim kering kemudian banjir dan tanah longsor ketika musim penghujan datang (Giantara, Yanti, Handayani, \& Anis, 2020). Perubahan iklim yang terjadi di seluruh belahan dunia menambah peningkatan peristiwa bencana (Sadeka, Mohamad, \& Sarkar, 2020). Beberapa faktor ini menjadi pemicu peristiwa bencana seperti gempa, tsunami, kebanjiran, tanah longsor, kebakaran lahan dan hutan dan sebagainya.

Semua elemen masyarakat sangat diharapkan mampu mempersiapkan diri untuk mengurangi kehilangan, risiko dan dampak yang merugikan. Saat bencana melanda suatu daerah, maka korban yang berjatuhan juga tidak sedikit, mulai dari orang dewasa, lansia, bahkan anak usia dini. Dalam keseluruhan populasi tersebut, anak-anak mempunyai kecenderungan yang sangat besar menjadi korban bencana sehingga menjadi kelompok yang memerlukan perhatian dan perlakuan sebelum atau setelah kejadian bencana (Peek, Abramson, Cox, Fothergill, \& Tobin, 2018). Peningkatan jumlah lembaga PAUD dan Taman Kanak-Kanak yang sangat pesat beberapa tahun belakangan ini menjadikan perencanaan menghadapi kejadian bencana semakin penting diadakan (Purwani \& Fridani, 2019). Hal ini ditambah dengan jumlah anak di Indonesia berada di persentase 30,1\% dari keseluruhan populasi penduduk (Kementerian Pemberdayaan Perempuan dan Perlindungan Anak, 2019). Melihat kondisi tersebut, individu yang lemah perlu ini perlu mendapatkan prioritas dari guru, sekolah, orangtua pemerintah maupun masyarakat dalam hal peningkatan pengetahuan dan pengertian mengenai manajemen bencana.

Anak usia dini adalah generasi masa depan yang akan meneruskan pembangunan dan mewujudkan cita-cita bangsa. Keberadaannya memiliki peran penting, sehingga tidak mengherankan jika anak usia dini menjadi preferensi baik secara nasional maupun internasional dalam kebijakan yang berkaitan dengan manajemen bencana. Hal ini dapat dilihat pada program Sustainable Development Goals (SDG's) pada tahun 2030, dimana salah satu target utamanya adalah anak (United Nations, 2015) dan Sendai Frame Work 2015-2030 (UNISDR, 2015) yang menempatkan anak usia dini sebagai komponen yang signifikan dalam tindakan manajemen risiko bencana. Dapat dikatakan bahwa anak adalah kelompok yang sangat rentan terhadap bencana (Cutter, 2017). Data UNICEF menyatakan bahwa total anak yang menjadi korban bencana alam secara global mencapai 535 juta anak (UNICEF, 2017)

Meskipun anak usia dini sangat rentan terhadap bencana, namun dengan dukungan yang tepat dari berbagai pihak akan mengurangi dampak dan risiko (Akhter et al., 2015). Salah satu dari dukungan tersebut dengan memberikan kesempatan untuk mengenal bencana dan melatih tentang bagaimana cara menyelamatkan diri dalam kondisi darurat. Seperti menyediakan berbagai media pembelajaran, bahan bacaan, dan kurikulum yang terintegrasi dengan managemen bencana (Mutasa \& Munsaka, 2019). Orang tua dan guru dapat melibatkan anak secara aktif dalam berbagai usaha untuk memperkenalkan bencana dan ancaman yang menyertainya. Hal ini didukung oleh potensi anak usia dini yang memiliki potensi untuk mengerti dan memahami tentang berbagai peristiwa yang terjadi di sekitarnya, termasuk bencana (Maureen Mooney , Ruth Tarrant, Douglas Paton \& Johal, 2020). Selain itu, anak merupakan sosok yang fleksibel dan mampu membangun pengetahuan mengenai tindakan manajemen bencana melalui proses belajar mengajar yang sesuai dengan kebutuhannya (Mohammadinia et al., 2018).

Namun sebagian orang dewasa di sekitar anak kurang terlibat dalam rangka pengenalan manajemen bencana seperti kesiapsiagaan, pemulihan (Pfefferbaum, Pfefferbaum, \& Van Horn, 2018). Data yang dikemukakan oleh (Solfiah, Risma, \& Kurnia, 2019) di kota Pekanbaru bahwa guru TK/PAUD memiliki pengetahuan yang rendah mengenai manajemen bencana disebabkan oleh keterbatasan akses untuk mendapatkan 
pelatihan tentang bagaimana mengenal peristiwa bencana dan menyelamatkan diri. Sehingga anak lebih sering diibaratkan sebagai korban yang tidak memiliki kemampuan untuk berlindung dari ancaman bencana (Siregar \& Wibowo, 2019). Namun dengan dukungan yang tepat dari berbagai pihak akan mengurangi dampak dan risiko yang mungkin akan menimpa anak ketika kejadian bencana terjadi di sekitarnya (Akhter et al., 2015).

Manajemen bencana adalah mekanisme yang berkelanjutan, berkesinambungan dan terintegrasi yang bertujuan untuk meningkatkan mutu tahapan-tahapan yang berkaitan dengan pengamatan dan kajian bencana serta preventif, mitigasi, kesiapsiagaan, peringatan dini, penanganan saat masa krisis, pemulihan serta perbaikan ("Undang-undang Republik Indonesia no. 24 Tahun 2007," 2007). Dengan kata lain, dalam manajemen bencana terdapat beberapa langkah yang ditempuh oleh pemerintah, pelaku usaha dan masyarakat untuk mengurangi risiko dan menanggulagi bencana. Berbagai usaha tersebut juga tertuang dalam nawacita ke-7 yang melandasi program konservasi potensi alam, ekologi dan pengelolaan bencana (BNPB, 2015). Mengingat pentingnya tindakan manajemen bencana, maka semua elemen dalam masyarakat perlu untuk mempersiapkan diri, termasuk anak usia dini. Dengan kata lain, pendidik dan wali anak perlu menjalin komunikasi dan usaha untuk membentuk pengertian anak mengenai manajemen bencana. Diantaranya adalah dengan memberikan kesempatan membaca buku cerita bergambar selain menyenangkan dan memenuhi kebutuhan tahap perkembangan anak (Solfiah, Risma, \& Kurnia, 2020).

Rangkaian manajemen bencana terdiri dari beberapa aktivitas yang berkaitan antara satu aspek dengan yang lainnya serta terdiri dari berbagai disiplin ilmu. Berbagai sektor dalam kehidupan masyarakat dilibatkan, salah satunya adalah pendidikan. Melalui bidang ini diharapkan anak membangun pengetahuan sedini mungkin tentang rantaian aktivitas yang bermanfaat dalam pengurangan dampak negatif dari bencana. Dengan kata lain, ini adalah langkah nyata dalam mengendalikan bencana sehingga akan mengurangi korban karena dapat ditangani dengan sigap dan akurat selain itu akan membantu percepatan masa pemulihan setelah bencana (Anies, 2018).

Salah satu usaha tersebut adalah dengan menggunakan buku cerita bergambar. Biasanya buku ini tersedia di kelas-kelas anak usia dini maupun di rumah. Jenis buku yang satu ini memiliki kekhususan yang menggabungkan tulisan dan gambar (Batič, 2019). Melalui buku tersebut anak usia dini akan memperoleh informasi yang terdiri dari gambar, warna, tokoh dan cerita. Membaca buku cerita bergambar memungkinkan anak usia dini belajar berbagai hal dengan konteks dan suasana yang berbeda (Chen, Lawrence, Zhou, Min, \& Snow, 2018). Seperti halnya membaca buku bersama teman, guru, orang tua dan bahkan dengan saudara kandungnya di rumah. Konteks yang terdapat dalam buku tersebut juga akan memberi pengalaman dan pemahaman yang menantang bagi anak. Setelah selesai membaca buku cerita bergambar, guru akan menanyakan kembali mengenai jalan ceritanya kepada anak serta menyampaikan pesan-pesan yang terkandung di dalamnya. Sebagian besar anak dapat mengulang alur cerita sesuai dengan bahasa pada tahap usianya (Filipović, 2018). Hal ini menunjukkan bahwa anak mempunyai kompetensi mengulang kembali cerita yang tertera di buku cerita bergambar setelah dibacakan oleh guru maupun orang tua.

\section{METODOLOGI}

Metode riset menggunakan eksperimen dengan bentuk quasi eksperimen dimana menggunakan buku cerita bergambar dalam rangka mempengaruhi pengetahuan manajemen bencana anak di Taman Kanak-kanak Terpadu FKIP Universitas Riau, Pekanbaru, Provinsi Riau. Riset eksperimen merupakan studi yang berkaitan dengan manipulasi terhadap variabel yang satu dengan yang lainnya dan menyimpulkan seperti apa efeknya setelah dilakukan perlakuan terhadap variabel tersebut (Ary, Jacobs, Sorensen, \& Razavieh, 2010). Melalui disain penelitian ini, maka peneliti ingin melihat efek buku cerita bergambar terhadap pengetahuan manajemen bencana anak. 
Teknik pengambilan sampel menggunakan purposive sampling. Dipilihnya ternik ini berdasarkan pertimbangan tertentu (Sugiyono, 2019). Adapun beberapa pertimbangan tersebut adalah penduduk Pekanbaru sebagian besar berasal dari luar daerah Pekanbaru (Kabupaten Kampar, Rokan Hulu, Rokan Hilir, Pelalawan, Indragiri Hulu, Indragiri Hilir, Taluk Kuantan, Bengkalis, Siak, Selat Panjang, dan Kota Dumai ) dan Provinsi Riau (Lusiana, 2015). Daerah tersebut rawan akan bencana alam seperti Provinsi Sumatera Barat, Jambi, Palembang dan Lampung. Pertimbangan yang selanjutnya adalah TK Labor FKIP Universitas Riau dijadikan sebagai laboratorium pengembangan pembelajaran PAUD dan Tempat Uji Kompetensi Guru di Provinsi Riau.

Jumlah sampel dalam penelitian ini ditetapkan sebanyak 48 anak. Disain eksperimen dalam penelitian ini menggunakan one group pre-test dan post-test . Sekelompok anak diberikan pre-test berupa tes pengetahuan manajemen bencana melalui wawancara. Langkah selanjutnya adalah treatment berupa penggunakaan buku cerita bergambar yang terdiri dari beberapa topik bencana seperti gempa, tsunami, banjir, tanah longsor dan kebakaran lahan dan hutan (Solfiah, Yeni, Risma, Devi, Hukmi, Kurnia, 2019). Guru memanfaatkan buku seri pengenalan bencana dalam kegiatan pembelajaran baik itu kegiatan diawal maupun di akhir pertemuan. Anak juga dapat melisankan atau pun menuturkan isi cerita pada pojok membaca yang tersedia di dalam kelas. Selanjutnya melaksanakan post-test dimana anak mendapatkan beberapa pertanyaan yang berkaitan dengan pengetahuan manajemen bencana.

Provinsi Riau dipilih sebagai tempat penelitian berdasarkan persentase tertinggi jumlah anak (35,5\%) di Indonesia pada tahun 2018 (Kementerian Pemberdayaan Perempuan dan Perlindungan Anak, 2019). Selain itu, provinsi Riau juga merupakan daerah yang rawan akan bencana banjir, longsor, dan kebakaran lahan dan hutan (Apinio, 2019). Berdasarkan hal ini, maka anak usia dini diharapkan mendapatkan bekal pengetahuan mengenai berbagai tindakan manajemen bencana. Salah satunya dengan penggunaan buku cerita bergambar yang memudahkan anak dan guru untuk menggunakannya baik secara individual di pojok baca maupun secara berkelompok ketika kegiatan pembukaan dan penutupan pembelajaran. Adapun disain dari penelitian ini tertera pada gambar 1 berikut:

Pre-test

Pengetahuan Manajemen

Pengatahuan Bencana Anak
Post-test

Pengetahuan Manajemen

Pengatahuan Bencana Anak

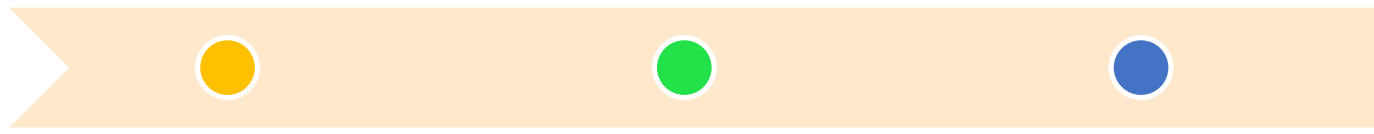

Treatment

Buku Cerita Bergambar

\section{Gambar 1. Tahapan Penelitian}

Pengetahuan manajemen bencana diperoleh dari subjek dalam bentuk data pre-test dan post-test melalui tes: 
Tabel 1. Kisi-Kisi Instrumen Pengetahuan Manajemen Bencana

\begin{tabular}{|c|c|c|}
\hline Aspek & Indikator & Cukup Kurang \\
\hline Mitigasi & $\begin{array}{l}\text { a. Mengetahui Jenis Bencana. } \\
\text { b. Mengetahui pencegahaan terhadap } \\
\text { bencana. } \\
\text { c. Mengetahui dampak bencana }\end{array}$ & \\
\hline $\begin{array}{l}\text { Preparedness } \\
\text { (kewaspadaan) }\end{array}$ & $\begin{array}{l}\text { a. Mengetahui rencana tindak yang } \\
\text { dilakukan dalam keadaan darurat } \\
\text { sesuai dengan jenis bencana. }\end{array}$ & \\
\hline $\begin{array}{l}\text { Response } \\
\text { (tanggapan) }\end{array}$ & $\begin{array}{l}\text { a. Mengetahui langkah-langkah } \\
\text { penyelamatan diri ketika ada } \\
\text { bencana. } \\
\text { b. Mengetahui cara mempertahankan } \\
\text { diri setelah terjadi bencana }\end{array}$ & \\
\hline $\begin{array}{l}\text { Recovery } \\
\text { (pemulihan) }\end{array}$ & a. Mengetahui rencana pemulihan. & \\
\hline
\end{tabular}

Data mengenai pengetahuan manajemen bencana anak diperoleh melalui tes dalam bentuk 7 pertanyaan setelah itu skor yang diperoleh anak kategorikan dalam tiga jenis seperti baik, cukup dan kurang. Kriteria kurang bila anak mampu menjawab 0-2 pertanyaan dengan benar dan memperoleh kategori kurang. Sementara bila anak mampu menjawab 3-5 pertanyaan maka akan berada dalam kelompok cukup dan yang mampu menjawab 6-7 pertanyaan berada dalam golongan yang memiliki pengetahuan baik.

Data mengenai pengetahuan anak yang telah dikumpulkan akan ditabulasi dalam bentuk tabel sesuai dengan kebutuhan penelitian, selanjutnya akan dianalisis. Informasi ini akan dikumpulkan dalam bentuk data kuantitatif. Proses analisis data menggunakan teknik statistik dengan uji t.

\section{HASIL DAN PEMBAHASAN}

Keterangan yang diperoleh dalam studi ini berasal dari variabel bebas (buku cerita bergambar) dan variabel atribut (pengetahuan manajemen bencana). Sebelum melaksanakan treatment kepada anak, maka dilaksanakan pre-test dengan tujuan mengetahui sejauh mana pengetahuan anak mengenai variabel atribut. Adapun hasil pre-test tertera di Tabel 2:

Tabel. 2. Skor Indikator Pengetahuan Manajemen Bencana pada Anak Sebelum Perlakuan (pretest)

\begin{tabular}{|c|c|c|c|c|c|c|c|}
\hline No & Indikator & $\begin{array}{l}\text { Jumlah } \\
\text { Item }\end{array}$ & $\begin{array}{l}\text { Skor } \\
\text { Ideal }\end{array}$ & $\begin{array}{l}\text { Skor } \\
\text { Faktual }\end{array}$ & $\begin{array}{l}\text { Rata- } \\
\text { Rata }\end{array}$ & $\%$ & Kategori \\
\hline 1 & $\begin{array}{l}\text { Mengetahui Jenis, pencegahan, dan } \\
\text { dampak bencana }\end{array}$ & 3 & 432 & 215 & 4,5 & $49,77 \%$ & Rendah \\
\hline 2 & $\begin{array}{l}\text { mengetahui rencana tindakan yang } \\
\text { dilakukan dalam keadaan darurat }\end{array}$ & 1 & 144 & 69 & 1,4 & $47,92 \%$ & Rendah \\
\hline 3 & $\begin{array}{lrr}\text { Mengetahui } & \text { langkah-langkah } \\
\text { penyelamatan } & \text { diri } & \text { dan } \\
\text { mempertahankan } & \text { diri } & \text { ketika } \\
\text { becana } & & \end{array}$ & 2 & 288 & 136 & 2,8 & $47,22 \%$ & Rendah \\
\hline 4 & $\begin{array}{l}\text { mengetahui rencana pemilihan } \\
\text { setelah bencana }\end{array}$ & 1 & 144 & 63 & 1.3 & $43.75 \%$ & Rendah \\
\hline & Jumlah & 7 & 1008 & 483 & 10.1 & $47.92 \%$ & Rendah \\
\hline
\end{tabular}


Dari Tabel 2 di atas dapat dilihat skor indikator pengetahuan manajemen bencana pada anak yaitu 483 atau 47,92\% dari yang diharapkan. Artinya pengetahuan manajemen bencana anak pada pre-test tergolong rendah. Kondisi ini berdampak negatif pada usaha peningkatan kesadaran pentingnya pemahaman dan pelatihan pendidikan kebencanaan. Sebaliknya di Jepang, peningkatan pengetahuan manajemen bencana telah dilaksanakan di semua jenjang pendidikan, termasuk Taman kanak-kanak (Budianto, 2017). Adanya usahausaha tersebut memberikan manfaat yang besar dalam rangka penurunan jatuhnya korban ketika bencana datang.

Untuk melihat gambaran subjek yang sebenarnya dapat diketahui di tabel kategori skor di bawah ini:

Tabel. 3. Kategori Skor Subjek Penelitian

\begin{tabular}{llll}
\hline Kategori & Skor & Frekuensi & $\%$ \\
Tinggi & $X \geq 16.33$ & 0 & $0.00 \%$ \\
Sedang & $14 \leq X<16.33$ & 2 & $4,17 \%$ \\
Rendah & $X<14$ & 46 & $95,83 \%$ \\
Jumlah & & $\mathbf{4 8}$ & $\mathbf{1 0 0 . 0 0 \%}$ \\
\hline
\end{tabular}

Dari Tabel 3 di atas diketahui 46 subjek menempati posisi kategori rendah, dan sisanya 2 anak berada pada golongan sedang dan 0 orang pada kelompok tinggi. Melihat rata-rata dari bukti diketahui yaitu 10,06 maka dapat disimpulkan pengetahuan manajemen bencana anak pada anak dikategorikan rendah.

Setelah pengambilan data pre-test, maka dilanjutkan dengan treatment kepada anak usia dini melalui proses pembelajaran di kelas. Guru menggunakan buku cerita bergambar sebagai bahan pembelajaran pada kegiatan story telling di kegiatan penutupan setiap harinya selama seminggu. Proses penyampaian pengetahuan manajemen bencana berlangsung secara menyenangkan dan partisipasi aktif anak. Guru memberi peluang kepada anak untuk sekedar menanyakan dan mempraktekkan langsung bagaimana cara menyelamatkan diri ketika bencana terjadi. Misalnya ketika terasa gempa, anak diminta untuk berlindung di bawah meja, namun jika anak sedang berada di luar ruangan maka tindakan penyelamatan diri dilakukan dengan mencari tanah yang lapang dan menjauhi pohon besar, tiang listrik, papan iklan dan bangunan yang tinggi. Pondasi pengetahuan manajemen bencana yang anak peroleh di sekolah akan disebarkannya ketika sampai di rumah. Anak akan dengan mudah menceritakan pengalamannya di kelas bersama temen sebaya dan gurunya kepada orang tua dan saudara kandungnya di rumah atau pun kepada masyarakat di sekitar lingkungan rumahnya (Efthymis et al., 2014). Dalam hal ini anak akan mampu berperan sebagai agen perubahan bagi setiap individu yang ada di sekitarnya. Gambar kegiatan guru bersama anak tertera pada gambar 2 :

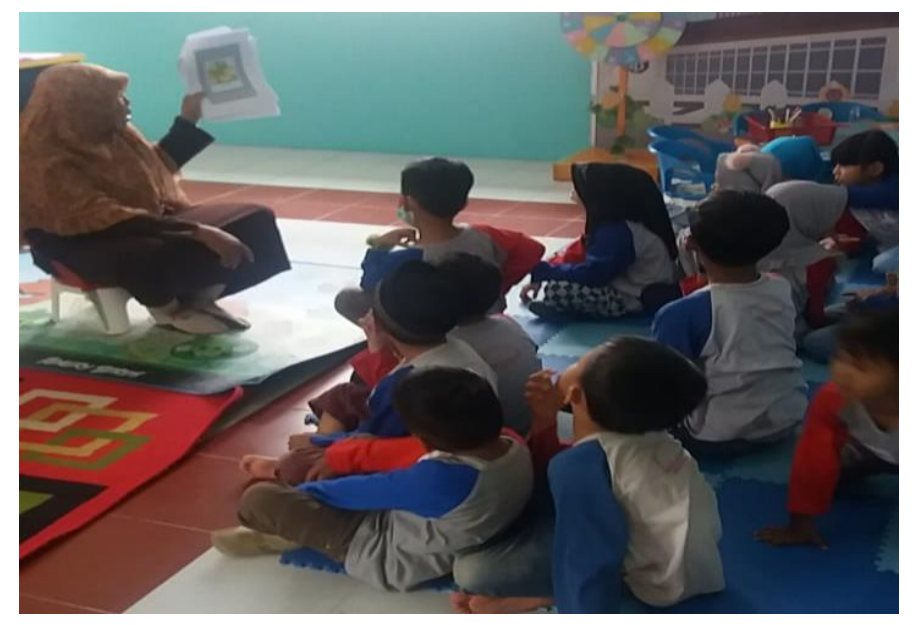

Gambar 2. Guru Menggunakan Buku Cerita Bergambar untuk Mengenalkan Manajemen Bencana 
Langkah selanjutnya adalah melaksanakan post-test melalui tes pengetahuan anak berkaitan dengan manajemen bencana. Peneliti mengajukan 7 pertanyaan kepada anak melalui percakapan yang ringan. Adapun uraian dari data post-test ini tertera pada Tabel. 4:

Tabel. 4. Skor Indikator Pengetahuan Manajemen Bencana Anak Sesudah Perlakuan (Posttest)

\begin{tabular}{llllllll}
\hline No & $\begin{array}{l}\text { Jumlah } \\
\text { Indikator }\end{array}$ & $\begin{array}{l}\text { Skor } \\
\text { Ideal }\end{array}$ & $\begin{array}{l}\text { Skor } \\
\text { Faktual }\end{array}$ & $\begin{array}{l}\text { Rata- } \\
\text { Rata }\end{array}$ & \% & Kategori \\
$\mathbf{1}$ & $\begin{array}{l}\text { Mengetahui Jenis, pencegahan, } \\
\text { dan dampak bencana }\end{array}$ & 3 & 432 & 345 & 7,2 & $79,86 \%$ & Tinggi \\
$\begin{array}{l}\text { Mengetahui rencana tindakan } \\
\text { yang dilakukan dalam keadaan } \\
\text { darurat }\end{array}$ & 1 & 144 & 108 & 2.3 & $75 \%$ & Cukup \\
$\begin{array}{l}\text { Mengetahui langkah-langkah } \\
\text { penyelamata diri dan } \\
\text { mempertahankan diri ketika } \\
\text { becana } \\
\text { Mengetahui rencana pemilihan } \\
\text { setelah bencana }\end{array}$ & 1 & 288 & 215 & 4.5 & $74,65 \%$ & Cukup \\
Jumlah & 7 & 144 & 107 & 2.2 & $74.31 \%$ & Cukup \\
\hline
\end{tabular}

Berdasarkan Tabel 4 diperoleh persentase pengetahuan manajemen bencana anak pada post-test berada pada kelompok yang tinggi dengan 78,88\%. Berdasarkan data tersebut, maka dapat digambarkan bahwa pengetahuan anak setelah perlakuan mengalami perubahan yang berarti. Artinya yang digunakan oleh guru dapat mempengaruhi informasi dan pengetahuan anak mengenai manajemen bencana. Hal yang sama disampaikan oleh (Lin, 2012) bahwa buku cerita bergambar membantu anak menginterpretasikan pesan yang terkandung di dalamnya selain itu juga mampu meningkatkan imaginasi, perasaan, dan perkembangan mentalnya ke arah yang positif.

Untuk melihat kondisi subjek yang sebenarnya dapat diperhatikan di tabel 5:

Tabel. 5. Kategori Skor Indikator Anak

\begin{tabular}{llll}
\hline Kategori & Skor & Frekuensi & \% \\
\hline Tinggi & $X \geq 16.33$ & 20 & $41.67 \%$ \\
Sedang & $14 \leq X<16.33$ & 22 & $54.17 \%$ \\
Rendah & $X<14$ & 4 & $4.17 \%$ \\
\hline Jumlah & & $\mathbf{4 8}$ & $\mathbf{1 0 0 . 0 0 \%}$ \\
\hline
\end{tabular}

Dari Tabel 5 di atas diperoleh 20 anak berada pada kelompok tinggi, 26 anak berada pada grup sedang dan 2 anak berada pada golongan rendah.

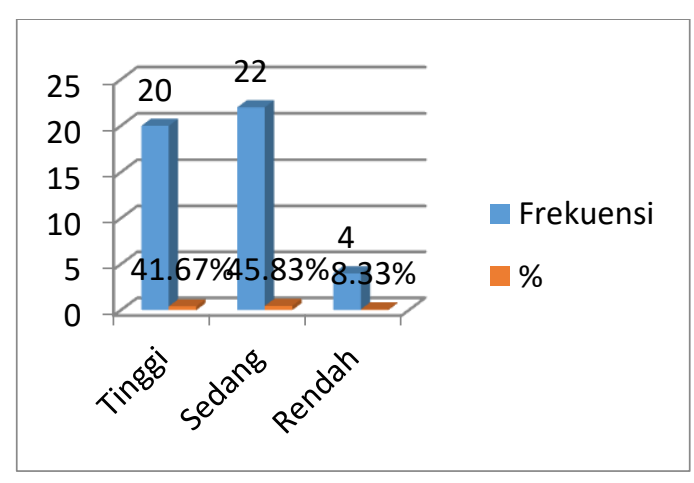

Gambar. 3 Kategori Skor Post-test Anak 
Uji prasyarat dilakukan melalui uji normalitas, linearitas, dan homogenitas dengan tujuan untuk mengetahui apakah dapat melaksanakan uji hipotesis menggunakan $t$-test dan mampu menjawab hipotesis. Uji prasyarat pada penelitian ini telah terpenuhi, maka layak untuk dilanjutkan kepada uji hipotesis. Untuk membuktikan adanya pengaruh bacaan cerita bergambar terhadap pengetahuan manajemen bencana pada anak maka dilakukan uji statistik $t$-test. Berdasarkan hasil uji-t maka diketahui nilai $t_{\text {hitung }}=25,790$ dan dengan nilai probabilitas sig $t=0,000$. Karena $\mathrm{p}<0,05$, sehingga dapat dirumuskan terdapat pengaruh yang signifikan sumber bacaan cerita yang memiliki gambar terhadap pengetahuan anak mengenai berbagai usaha-usaha manajemen bencana. Dalam rangka mengetahui seberapa besar pengaruh buku cerita bergambar terhadap pengetahuan manajemen bencana anak, menggunakan rumus gain menurut Meltzer (Herlanti, 2014). Hasilnya dapat digambarkan bahwa buku cerita bergambar memberikan pengaruh sebesar 55,6\% terhadap pengetahuan manajemen bencana pada anak.

Hasil penelitian pretest diperoleh hasil sebagai berikut: pada indikator mengetahui jenis, pencegahan, dan dampak bencana diperoleh skor 215 atau 49,77\% dari yang diharapkan. Berdasarkan nilai persentase yang didapatkan bahwa pada indikator mengetahui jenis, pencegahan, dan dampak bencana berada pada kelompok rendah. Hal ini senada dengan pernyataan (Kurniati, Adriany, El-seira, \& Winangsih, 2020) bahwa sebagian lembaga TK belum melaksanakan manajemen bencana kepada anak usia dini. Kondisi ini tentu akan berdampak pada minimnya pengetahuan anak mengenai berbagai tindakan yang perlu dilakukan saat darurat. Oleh karena itu, guru memiliki peran strategis dalam rangka pembentukan informasi dan pengertian mengenai bentuk, antisipasi beserta konsekuensi dari peristiwa bencana. Sehingga tidak berlebihan jika (Lee \& Chen, 2019) menyampaikan bahwa sekolah menjadi prioritas dalam pelaksanaan manajemen bencana, termasuk di dalamnya Taman Kanak Kanak (Lee \& Chen, 2019).

Sementara itu pada indikator mengetahui rencana tindakan yang dilakukan dalam keadaan darurat diperoleh skor 69 atau dengan persentase 47,92\% berada pada kelompok rendah. Berdasarkan temuan ini, digambarkan anak kurang mengetahui bagaimana cara merespon ketika peristiwa bencana terjadi. Kondisi ini tentu akan merugikan mengingat anak adalah penerus bangsa yang akan diharapkan melanjutkan pembangunan. Salah satu langkah yang ditempuh dalam membangun pengetahuan dan kesadaran anak dalam bertindak ketika peristiwa bencana terjadi adalah melalui pendidikan yang efektif dan akan menjadi bagian dari investasi masa depan (Imamura, Penmellen, Suppasri, \& Muhari, 2019).

Indikator mengetahui langkah-langkah penyelamatan diri dan mempertahankan diri masih tergolong rendah, untuk itu maka diperlukan beberapa usaha sehingga ke depannya anak mengenal tahapan bagaimana cara melindungi diri saat bencana terjadi. Seperti tidak panik, mengikuti jalur evakuasi dan menghindari benda yang membahayakan. Dengan demikian maka akan mengurangi jatuhnya korban dan dampak berkepanjangan setelah bencana terjadi seperti trauma, putus asa, kesedihan, gangguan tidur, kecemasan dan sebagainya (Jones \& Schmidt, 2013).

Selanjutnya pada indikator mengetahui rencana pemulihan setelah bencana diperoleh skor 63 atau 43,75\%. Berdasarkan persentase tersebut dapat digambarkan bahwa pengetahuan anak pada kategori ini masih tergolong rendah. Hal ini bertolak belakang dengan pernyataan (Gibbs et al., 2015) bahwa anak memiliki kemampuan mengenali dan mengatasi tantangan setelah bencana serta mendukung pengambilan keputusan penting tentang kehidupan pasca bencana (Gibbs et al., 2015). Dengan adanya dukungan dan latihan yang berlangsung terus menerus akan membentuk anak memiliki keterampilan dalam proses rehabilitasi setelah bencana. Seperti yang dilaksanakan oleh Jepang dalam mempersiapkan anak usia dini dalam proses manajemen bencana, termasuk di dalamnya proses perbaikan setelah peristiwa bencana (Adiyoso, 2018). 
Berdasarkan hasil post-test maka diperoleh hasil sebagai berikut: pada indikator mengetahui jenis, pencegahan, dan dampak bencana diperoleh skor 345 atau $79,86 \%$. Selanjutnya pada indikator mengetahui rencana tindakan yang dilakukan dalam keadaan darurat diperoleh skor 108 atau 75\%. Untuk indikator mengetahui langkah-langkah penyelamatan diri dan mempertahankan diri ketika bencana diperoleh skor 215 atau 74,65\%. Sementara itu, indikator mengetahui rencana pemulihan setelah bencana diperoleh skor 107 atau $74,31 \%$. Dapat disimpulkan pengetahuan manajemen bencana anak pada post-test berada dalam kelompok tinggi.

\section{Pengetahuan Manajemen Bencana pada Anak}

Indonesia adalah negara kepulauan yang beriklim tropis yang menyimpan berbagai kapasitas dan sumber daya alamiah, pariwisata perkebunan dan industri. Namun, disisi lain wilayah ini tidak terlepas dari bencana alam, seperti banjir, kabut asap, kebakaran hutan, gempa bumi, gunung berapi dan tsunami. Saat terjadi bencana, anak usia dini merupakan elemen yang paling rentan menjadi korban hal ini karena keterbatasan pengetahuan dan informasi. Untuk mencoba mengatasi jatuhnya korban, maka sekolah menjadi salah satu agen sosialisasi penting mengenai peningkatan pengetahuan manajemen bencana. Oleh sebab itu, perlu adanya materi pembelajaran dan bahan bacaan sebagai sumber belajar mengenai manajemen bencana mulai sejak usia dini. Rangkaian materi dan bahan bacaan ini akan menjadi sumber pengetahuan bagi anak mengenai manajemen bencana sehingga akan mengurangi korban, resiko, kerugian dan dampak setelah bencana. Seperti halnya yang telah dilakukan di Jepang, bahwa pendidikan manajemen bencana menjadi bagian dari kurikulum nasional di semua jenjang pendidikan dan memberikan hasil yang sangat baik dimana meminimalisir korban jiwa di setiap peristiwa bencana (Sakurai, Sato, \& Murayama, 2020).

Pengetahuan manajemen bencana pada anak usia dini dapat diukur dengan baik, cukup atau pun kurang dengan indikator yang menjadi penilaian adalah (1) mengetahui jenis, pencegahan, dan dampak bencana, (2) mengetahui rencana tindakan yang dilakukan dalam keadaan darurat, (3) mengetahui langkah-langkah penyelamatan diri dan mempertahankan diri ketika bencana, (4) mengetahui rencana pemulihan setelah bencana. Guru menggunakan buku cerita bergambar dalam kegiatan pembukaan ataupun penutupan pembelajaran di kelas. Anak dengan aktif bertanya mengenai gambar, tokoh, warna, tindakan penyelamatan dan alur cerita yang ada di buku. Selanjutnya, pendidik dan peserta didik juga mempraktekkan langsung bagaimana cara melindungi diri dari bencana. Dapat dikatakan bahwa pengalaman membaca buku bersama antara teman sekelas, anak dan guru memiliki arti penting sehingga perlu untuk ditingkatkan kuantitas dan kualitasnya dalam proses pembelajaran (Dynia \& Justice, 2015). Aktivitas ini menumbuhkan perhatian dan minat anak sehingga informasi dapat diterima dengan baik. Dengan adanya isi cerita yang melengkapi indikator manajemen bencana, maka pengetahuan anak juga meningkat. Sejalan dengan yang disampaikan oleh (Wang, 2016) bahwa sekolah dalam hal ini dapat menyebarluaskan informasi berupa kebijakan, kurikulum, media dan kegiatan pembelajaran mengenai penanggulangan bencana kepada masyarakat luas.

Sebelum melakukan treatment diketahui bahwa pengetahuan manajemen bencana pada anak masih dikategorikan rendah dengan penilaian dilakukan menggunakan tes dalam bentuk wawancara. Setelah pre-test tersebut guru melakukan treatment menggunakan buku cerita bergambar yang mana isi cerita telah memenuhi indikator manajemen bencana. Setelah melakukan treatment tahap selanjutnya adalah post-test dengan kembali memberi tes pada anak. Hasil dari post-test tersebut ada perubahan yaitu pengetahuan manjemen bencana pada anak dikategorikan baik sehingga dikatakan bahwa buku cerita bergambar berpengaruh signifikan dengan pengetahuan manajemen bencana pada anak. Pada saat guru menyampaikan cerita, maka terjadi percakapan antara guru dan anak terkait pencegahan bencana. Komunikasi dua arah saat membacakan buku mendukung anak 
membentuk pemahamannya mengenai berbagai hal yang berkaitan dengan bagaimana cara menyelamatkan diri sebelum, saat terjadi dan setelah terjadinya bencana (Nakamura, Umeki, \& Kato, 2016).

\section{SIMPULAN}

Hasil akhir riset dirumuskan buku cerita bergambar dapat mempengaruhi pengetahuan anak tentang manajemen bencana. Melalui sumber bacaan yang bermanfaat, orang tua dan guru dapat memperkenalkan berbagai tindakan manajemen bencana dalam suasana yang menyenangkan dan menarik minat anak. Selain membaca, buku tersebut dapat dijadikan sebagai panduan untuk berlatih berbagai tindakan mitigasi, penyelamatan dan pemulihan setelah bencana terjadi. Sehingga pesan yang terdapat pada buku tersebut sampai kepada anak dan menjadikannya sebagai wawasan mengenai bagaimana cara mengenali jenis-jenis bencana, tindakan saat bencana dan setelah peristiwa bencana. Selanjutnya, buku cerita bergambar dapat dijadikan pilihan sumber belajar yang fleksibel untuk memenuhi kebutuhan dan kondisi anak.

\section{UCAPAN TERIMA KASIH}

Tim peneliti mengucapkan terima kasih kepada LPPM Universitas Riau yang telah memberikan suport dana riset dan Taman Kanak-kanak Terpadu FKIP Universitas Riau yang telah memberi kesempatan untuk melaksanakan penelitian.

\section{DAFTAR PUSTAKA}

Adiyoso, W. (2018). Manajemen Bencana. Jakarta: Bumi Aksara.

Akhter, S. R., Sarkar, R. K., Dutta, M., Khanom, R., Akter, N., Chowdhury, M. R., \& Sultan, M. (2015). Issues with families and children in a disaster context: A qualitative perspective from rural Bangladesh. International Journal of Disaster Risk Reduction, 13, 313-323. https:// doi.org/10.1016/j.ijdrr.2015.07.011

Anies. (2018). Manajemen bencana. Yogyakarta: Gosyen.

Apinio, R. (2019). Riau Berstatus Siaga Darurat Banjir dan Longsor hingga Akhir Tahun Baca selengkapnya di artikel "Riau Berstatus Siaga Darurat Banjir dan Longsor hingga Akhir Tahun." Retrieved from https://tirto.id/riau-berstatus-siaga-darurat-banjir-danlongsor-hingga-akhir-tahun-enW5

Ary, D., Jacobs, L. C., Sorensen, C., \& Razavieh, A. (2010). Introduction to Research in Education (8th ed.). Belmont.

Batič, J. (2019). Reading Picture Books in Preschool and Lower Grades of Primary School. Center for Educational Policy Studies Journal, (November), 1-18. https:/ / doi.org/10.26529/cepsj.554

BNPB. (2015). Rencana Strategis BNPB 2015-2019. Jakarta: BNPB.

Budianto, F. (2017). Habitus Kesiapsiagaan Masyarakat Jepang Terhadap Bencana. Jurnal Kajian Jepang, 1(Oktober), 49. Retrieved from file:/ / D:/ Firman Budianto, 2018.pdf

Chen, S., Lawrence, J. F., Zhou, J., Min, L., \& Snow, C. E. (2018). The efficacy of a schoolbased book-reading intervention on vocabulary development of young Uyghur children: A randomized controlled trial. Early Childhood Research Quarterly, 44, 206219. https:// doi.org/10.1016/j.ecresq.2017.12.008

Cutter, S. L. (2017). The forgotten casualties redux: Women, children, and disaster risk. Global Environmental Change, 42, 117-121. https:// doi.org/10.1016/j.gloenvcha.2016.12.010

Dynia, J. M., \& Justice, L. M. (2015). Special Education Classrooms. I, 232-269. https:/ / doi.org/10.1080/02702711.2013.843065

Efthymis, L., Michael, S., Alexia, G., Panagiotis, P., Vassiliki, A., Kate, V., \& Spyros, P. (2014). Disaster Data Centre-An Innovative Educational Tool for Disaster Reduction through Education in Schools. Journal of Power and Energy Engineering, 02(09), 35-40. https:// doi.org/10.4236/jpee.2014.29006 
Filipović, K. (2018). Gender Representation in Children's Books: Case of an Early Childhood Setting. Journal of Research in Childhood Education, 32(3), 310-325. https://doi.org/10.1080/02568543.2018.1464086

Garschagen, M. (2016). World Risk Report 2016. In 25 August. Retrieved from https://translate.googleusercontent.com/translate_c?anno=2\&client=srp\&depth $=1 \&$ $\mathrm{hl}=\mathrm{id} \& \mathrm{prev}=$ search\&rurl=translate. $g$ oogle.com\&sl=en\&sp=nmt4\&tl=id\&u=https://c ollections.unu.edu/view/UNU:5763\&usg=ALkJrhg3abgs7urWhAJDU9Vd0X2tKL16w

Giantara, F., Yanti, N., Handayani, S., \& Anis, Y. (2020). Jurnal Obsesi : Jurnal Pendidikan Anak Usia Dini Pola Pendidikan keluarga Saat Bencana Kabut Asap di Kota Pekanbaru Abstrak. 4(2), 778-786. https:// doi.org/10.31004/obsesi.v4i2.446

Gibbs, L., Block, K., Harms, L., Macdougall, C., Baker, E., Ireton, G., ... Waters, E. (2015). International Journal of Disaster Risk Reduction Children and young people' $\mathrm{s}$ wellbeing post-disaster: Safety and stability are critical. International Journal of Disaster Risk Reduction, 1-7. https:// doi.org/10.1016/j.ijdrr.2015.06.006

Herlanti, Y. (2014). Tanya jawab seputar penelitian sains. Jakarta: Pendidikan Ilmu Pengetahuan Alam Fakultas Ilmu Tarbiyah dan Keguruan. Universitas Syarif Hidayatulah.

Imamura, F., Penmellen, S., Suppasri, A., \& Muhari, A. (2019). Progress in Disaster Science Recent occurrences of serious tsunami damage and the future challenges of tsunami disaster risk reduction. 1, 0-3. https:// doi.org/10.1016/j.pdisas.2019.100009

Jones, S. L., \& Schmidt, C. K. (2013). Psychosocial Effectsof Disasterin Children and Adolescents Significance and Management. Nursing Clinics of NA, 48(2), 229-239. https://doi.org/10.1016/j.cnur.2013.01.005

Kementerian Pemberdayaan Perempuan dan Perlindungan Anak. (2019). Profil Anak Indonesia Tahun 2019.

Kurniati, E., Adriany, V., El-seira, R. M., \& Winangsih, I. (2020). Jurnal Obsesi: Jurnal Pendidikan Anak Usia Dini Identifikasi Kesiapsiagaan Guru PAUD sebagai Upaya Pengurangan Risiko Bencana Banjir di Bandung Abstrak. 4(2), 840-850. https://doi.org/10.31004/obsesi.v4i2.388

Lee, H., \& Chen, H. (2019). International Journal of Disaster Risk Reduction Implementing the Sendai Framework for disaster risk reduction 2015 - 2030: Disaster governance strategies for persons with disabilities in Taiwan. International Journal of Disaster Risk Reduction, 41(August), 101284. https://doi.org/10.1016/j.ijdrr.2019.101284

Lin, R. (2012). A Study of Creative Thinking for Children's Picture Book Creation. IERI Procedia, 2, 36-42. https://doi.org/10.1016/j.ieri.2012.06.048

Lusiana, V. (2015, April). Disdukcapil: Laju Pertumbuhan Penduduk Pekanbaru 7,43 Persen. Antara Riau. Retrieved from https:/ / riau.antaranews.com/berita/55179/disdukcapillaju-pertumbuhan-penduduk-pekanbaru-743-persen

Maureen Mooney , Ruth Tarrant, Douglas Paton, D. J. \& S., \& Johal. (2020). The school community contributes to how children cope effectively with a disaster. An International Journal of Personal, Social and Emotional Development. https://doi.org/https:// doi.org/10.1080/02643944.2020.1774632

Mohammadinia, L., Khorasani-Zavareh, D., Ebadi, A., Malekafzali, H., Ardalan, A., \& Fazel, M. (2018). Characteristics and components of children's and adolescents' resilience in disasters in Iran: a qualitative study. International Journal of Qualitative Studies on Health and Well-Being, 13(1). https://doi.org/10.1080/17482631.2018.1479584

Mutasa, S., \& Munsaka, E. (2019). Botswana and international policies on the inclusion of disaster risk reduction in the school curriculum: Exploring the missing link. International Journal of Disaster Risk Reduction, 40(April), 101271. https:// doi.org/10.1016/j.ijdrr.2019.101271

Nakamura, H., Umeki, H., \& Kato, T. (2016). Importance of communication and knowledge of disasters in community-based disaster-prevention meetings. Safety Science. 
https:// doi.org/10.1016/j.ssci.2016.08.024

Peek, L., Abramson, D. M., Cox, R. S., Fothergill, A., \& Tobin, J. (2018). Children and Disasters. 243-262.

Pfefferbaum, B., Pfefferbaum, R. L., \& Van Horn, R. L. (2018). Involving children in disaster risk reduction: the importance of participation. European Journal of Psychotraumatology, 9(sup2). https:/ / doi.org/10.1080/20008198.2018.1425577

Purwani, A., \& Fridani, L. (2019). Jurnal Obsesi: Jurnal Pendidikan Anak Usia Dini Pengembangan Media Grafis Untuk Meningkatkan Siaga Bencana Banjir. 3(1), 55-67. https:// doi.org/10.31004/obsesi.v3i1.142

Sadeka, S., Mohamad, M. S., \& Sarkar, M. S. K. (2020). Disaster experiences and preparedness of the Orang Asli Families in Tasik Chini of Malaysia: A conceptual framework towards building disaster resilient community. Progress in Disaster Science, 6, 100070. https:// doi.org/10.1016/j.pdisas.2020.100070

Sakurai, A., Sato, T., \& Murayama, Y. (2020). International Journal of Disaster Risk Reduction Impact evaluation of a school-based disaster education program in a city affected by the 2011 great East Japan earthquake and tsunami disaster. International Journal of Disaster Risk Reduction, 47(May), 101632. https:/ / doi.org/10.1016/j.ijdrr.2020.101632

Siregar, J. S., \& Wibowo, A. (2019). Upaya Pengurangan Risiko Bencana Pada Kelompok Rentan. Jurnal Dialog Penanggulangan Bencana, 10 N0.1(Juni, 2019), 30-38. Retrieved from https://bnpb.go.id/jurnal/jurnal-dialog-penanggulangan-bencana-vol10-no1tahun-2019

Solfiah, Yeni, Risma, Devi, Hukmi, Kurnia, R. (2019). Seri Pengenalan Bencana Untuk Anak Usia 4-6 Tahun. Pekanbaru: Taman Karya.

Solfiah, Y., Risma, D., \& Kurnia, R. (2019). The Knowledge Of Early Childhood Education Teachers About Natural Disaster Management. 2(1), 159-166.

Solfiah, Y., Risma, D., \& Kurnia, R. (2020). Early Childhood Disaster Management Media Through Picture Story Books. 14(1), 141-155.

Sugiyono. (2019). Metode Penelitian Kuantitatif Kualitatif dan R \& D. Bandung.

Undang-undang Republik Indonesia no. 24 Tahun 2007. (2007). Retrieved from https://bnpb.go.id/ppid/file/UU_24_2007.pdf

UNICEF. (2017). Annual Report 2016. Retrieved from https://www.unicef.org/publications/files/UNICEF_Annual_Report_2016.pdf

UNISDR. (2015). The Sendai Framework for Disaster Risk Reduction 2015-2030: the challenge for science. Royal Society Meeting Note, 9. https://doi.org/A/CONF.224/CRP.1

United Nations. (2015). Sustainable Development Goals. Retrieved September 25, 2020, from https:/ / sustainabledevelopment.un.org/?menu=1300

Wang, J. (2016). International Journal of Disaster Risk Reduction Study on the context of school-based disaster management. International Journal of Disaster Risk Reduction, 19, 224-234. https://doi.org/10.1016/j.ijdrr.2016.08.005 